\title{
Theological and Dogmatic Definition of the God-Man Jesus Christ Person
}

\author{
PhD. Marin Bugiulescu \\ Valahia University of Târgovişte, \\ ROMANIA, \\ E-mail:m_bugiulescu@yahoo.com
}

\begin{abstract}
The present paper presents the Theological and Dogmatic definition of the Person of the God-man Jesus Christ, as it has been formulated by the Orthodox Church in the course of time. In the Ecumenical and local synods, the Church proclaimed against the heresies various definitions of faith or dogmas. Dogma, in its essence, is a truth of faith revealed by God, unchangeable, formulated and transmitted by the Church, for man's salvation. The central dogma of Christianity is the Trinitarian one. Regarding the Person and the Work of Christ, against the heresies promoted by Arius, Nestorius, Eutychius and Macedonius, at the Ecumenical Synods III (Ephesus 431), IV (Chalcedon 451), VI (Constantinople 680-681), the Church officially stated that Jesus Christ is truly God and truly Man, and His Person includes the divine nature, from eternity, yet united in time with the human nature, each nature having its own will, and the human will follows the divine will. This union of the divinity with the humanity in Christ is actually the basis of man's salvation realized objectively in Christ and actualized personally by all the Christians in the Church, by means of which evil and death are defeated by the resurrection leading to eternal life.
\end{abstract}

Keywords: Jesus Christ, God-Man, dogmatic definition, theology

\section{INTRODUCTION}

The Person and especially the Activity of our Saviour Jesus Christ is the heart of the teaching of faith, because He is the One realizing the salvation of the world and of man by deliverance from the slavery of $\sin$ and death. The teaching about Jesus Christ the Embodied Son and Word of God (John 1:14; Hebrews 4:15) as it was formulated and preached by the Church in the Ecumenical and local Synods has been accepted by the Christian community becoming a dogma - a definition of faith and a norm of Christian life, definition of the right faith or the Orthodoxy.

Jesus Christ's person is formed of the two natures: - divine and human represent the perfect reality by which humanity is intimately united with divinity. This is why salvation is possible only by the union with God realized by Christ, true God and true Man. The formulation of the Christological norm was realized by the Orthodox Church when heresies emerged, solemnly proclaiming in the Synods the dogma of salvation. At the First Ecumenical Synod (Nicaea 325), the Church fights against Arius' wrong teaching, according to which Christ was subordinated to the Father; and the Synod proclaims that the divine being (the Godhead) comprises the Persons: Father, Son and Holy Spirit; at the Second Ecumenical Synod the Church formulates the teaching on the Holy Spirit as true God and along with it the teaching on the dogma of the Holy Trinity; at the Ecumenical Synods III (Ephesus 431), IV (Chalcedon 451) and VI (Constantinople 680-681), the Church defined the Christological dogma, which also comprises the work of 
Christ, the Embodied Son of God, realized outside the Triune Being, in time, in order to save man.

\section{The notion of person - premise for understanding the Christological dogma}

To correctly understand the Christological dogma, as it has been formulated by the Church, we need to get to know the notion of person via the explanations of the Cappadocian Fathers.

The term of "person" comes from the Greek prosopon ( $\pi \rho \circ \varsigma \dot{\omega} \pi \mathrm{ov})$ and the Latin persona, i.e. mask that used to cover the artists' face during the Antiquity, when they were interpreting a role. In this sense, man is seen as a concrete face, a real representation or a persona, as the Latins have translated this reality. By the term "person" attributed to man as well, one understands that man is a spiritual being. What makes man a person is not his body or his appearance, but his spirituality, his metaphysical dimension, which gives the whole psycho-physical organism the character of person.

By man's spiritual dimension, one understands the rational and free nature, selfknowing and self-determining. Yet, as a "person", man is not understood only according to his spiritual aspect, but especially according to his given dimension of "hypostasis", namely autonomous unity, as an entity whose centre of existence and life is in himself, permanently available to relating, open to the communication with the other relational beings, namely: the other people, the holy angels and, last but not least, the three divine persons of the Holy Trinity. Since "hypostasis" is the common name for all the concrete rational or un-rational individual existences (hypostasis-individual), the Christian theology used the term "person" for the rational, "spiritual" existences [1], while, for the un-rational ones, it used the term "individual". Each person is an autonomous unity (individual) and has its unique specific among the other persons (individuality). The Greek philosophy uses a lot the notion of individual, ignoring that of person. Yet, the Holy Fathers, in order to define the Holy Trinity, use the term person, a term which, after the Ecumenical Synod of Chalcedon (451), entered Christology and Christian anthropology with the implications of hypostasis included in the definition of the word person, which unlike being or matter or essence "defines the way of holding the unique human being and of participating to the unique divine life" [2]. The person is, therefore, a way of existence penetrating and making the whole being personal. The person is the subject and bearer to whom the being as such belongs and in whom the being as such lives [3].

Saint Basil the Great shows that ousia, essence, being, indicates the fundament of the common nature of several individuals, of the same species, which makes one thing be itself and not something else. The being is affirmed by the hypostasis, yet it is fully encompassed in each of the hypostases of the same species. For this reason, hypostases do not differ one from the other regarding the being, but regarding the accidents, namely the characteristic features. These characteristic features, however, belong to the hypostases and not to nature. "The hypostasis is defined as: the being together with its accidents. For this reason, the hypostasis possesses what is common together with the particular and the existence in itself. The being, however, does not exist in itself, but is considered in the hypostases" [4].

Regarding the being and its differentiation from the hypostasis, Saint Basil the Great says: "Therefore we understand that: What is specified in a particular manner is shown by the word hypostasis. Indeed, when you say "man", your ear receives - by the indefinite specification of this word - a quite vague idea, so that while nature is indicated 
using this denomination, what is implied and actually indicated by its name is not specified. On the contrary, when you say "Paul", then you show precisely the being indicated by this name... Ousia is the fundament of the nature common to several individuals of the same species for example: humanity, while hypostasis is the concrete individual: Peter, Paul, John" [5].

Certainly the term person with all its theological implications was defined by the Church to express first the Trinitarian dogma. In an ontological patristic sense, without person or hypostasis there is no being or nature and the other way round, with the mention that the hypostasis is the cause of the existence of the being. As the $4^{\text {th }}$ Ecumenical Synod of Chalcedon (431) remarks: person - prosopon is the psychological aspect of a being turned towards his own inner world, while hypostasis appears as the open being going beyond himself in the relation with God and fellows. The fact that "a hypostasis is what is constituted distinctly from self, if the hypostasis - as they (the Fathers) say - is the being with properties (with special personal features), differing in number from the other beings of the same kind" [6] does not involve at the Christological level a distinct hypostasis of the human nature (the individual), because human nature was enhypostatized by Christ, a teaching clarified by Saint Maximus the Confessor.

The theological concept of person supposes liberty from nature, alterity. The person is free from any determination. The human hypostasis cannot be fully realized except by his own will in renunciation and generosity toward other persons. Thus, the person of our fellow is really an image of God, absolutely necessary to communion. What corresponds in us to God's image is not a part of our being, but the person in the full nature, as Leontius of Byzantium shows by enhypostasis (غ́vï $\pi$ ó $\sigma \alpha \tau o v)$, a term defining the nature comprised in the hypostasis, thus nature being the content of the person and the person - the existence of the nature.

Taking into account all these, patristic theology affirms that each person reveals himself by enhypostatizing and this is why a hypostasis involves the person that one concretely relates to nature but also to the person's properties, to relating, to a certain state, showing how someone is. Although identical from a Christian perspective, between person and hypostasis there is no perfect synonymy, but we need to mention that the person is precisely the hypostasis of the being. Above all these, in the thinking of the Holy Fathers, man is defined as a theological being, situated in a direct and personal relation with God by his virtues. "Because man is neither just he who has hands and feet nor the rational man, but he who practices faith and virtue full of piety" [7]. In this sense, the natural ontological state of the human nature is the one of Christ the New Adam, a state made accessible to all and appropriated by every Christian sacramentally by the Church.

The Chalcedon formula uses the terms "hypostasis" and "prosopon", which mean person, yet with different nuances. Prosopon is the psychological aspect of the human being turned toward his inner world, toward self-conscience and in this quality follows his evolution going through the ages of his own knowledge and through the stages of the appropriation of the nature he bears. The hypostasis has the aspect of the being that opens himself and goes beyond himself toward another. This second aspect is decisive to understand the teandric dimension of the person, without forgetting that the Person in an absolute sense exists only in God and that any human person is but His "image" [8]. "The person finds his sense and happiness only in the unlimited richness of meanings and consequently in a living and in their infinite mutual communication with other persons 
and with the personal Word (Christ), infinite source of all the meanings, lover of all the persons in whom meanings are included." [9]

\section{Formulation of the Christological dogma in the Ecumenical Synods: III (Ephesus 431), IV (Chalcedon 451), VI (Constantinople 680-681)}

The Third Ecumenical Synod of Ephesus (431) condemns Nestorius who was blaspheming the Savior Jesus Christ and Mary the Virgin by his teaching as he was saying that Christ has two Persons: divine and human, the divine Person born since eternity from the Father and the human Person born in time from Mary the Virgin, whom he was considering only mother of man or mother of Christ, namely Antropotokos or Christotokos.

The Christological issue began with great impetus by the fight between Saint Cyril of Alexandria and Nestorius, who unites with Bishop John of Antioch to consolidate his heresy. In Rome, Pope Celestine in the year 430 in a synod declares Nestorius' teaching to be a heresy, and in Alexandria, Saint Cyril held a synod in which he presents 12 Anathematismata against Nestorius and his teaching. On the background of these disputes, the Synod of Ephesus (431) was convoked, which, based on the Cappadocians' and Saint Cyril's teaching condemns Nestorius and his wrong teaching, declaring in the synodal formula the Christological dogma: "We confess our Lord Jesus Christ, the Only Begotten Son of God, truly God and truly man, of a reasonable soul and body; begotten of the Father before the ages according to the Godhead, and in the latter days, the Same, for us and our salvation, born of Mary the Virgin according to the manhood, the Same consubstantial with the Father in the Godhead, and consubstantial with us in manhood, for a union of two natures took place. For this reason, we confess one Christ, one Son, one Lord. According to this meaning of the unconfused union we confess the holy Virgin to be Theotokos, because God the Word was made flesh and lived as a man, and from the very conception united to Himself the temple taken from her. .." [10].

Our Saviour Jesus Christ, speaking about Himself, attributes to Himself a Divine nature and a human nature, calling Himself Son of God and Son of Man. In the dialogue with Nicodemus, he reveals His divine nature calling Himself the One-Born Son of God, therefore having a divine nature, Who came down from heaven by embodiment, yet existing in heaven as God (John 3:15, 16, 18).

In the dogmatic definition of the Third Ecumenical Synod, Christ is called truly God and truly man, having a rational soul and being of a human body, yet being the same (of the same being) with the Father according to the Godhead and of the same being with man according to the humanity taken by Him as a body, certainly except for sin, by the birth of the Holy Spirit and of Mary the Virgin.

The Holy Fathers, faced with numerous Christological heresies, are unanimous in teaching about the two natures (divine and human) in Christ, defined as Son of Man and Son of God, and so they formulated clear and precise evidence based on the Holy Scripture, but also a series of rational arguments in this sense, out of which we shall remind:

- as a Mediator between God and man, Christ has to be God and man (1 Tim. 2:5).

- as a perfect teacher, as the Light of the world (John 8:12), the Savior has to be God-man (Luke 4:18), this is why no one else could have announced the Father to the world except for His hypostatic Word (Romans 11:34) 
- as a Redeemer and Restorer of the human nation (Galatians 3:13; Hebrews 12:22), the Saviour Jesus Christ had to belong to both the Godhead and mankind.

The Christological dogma reaches its complete depth in the Sixth Ecumenical Synod of Chalcedon (451). Eutychius, one of the fiercest fighters against Nestorius, interprets completely at the opposite pole the union of the two natures in the Person of Christ, the Son of God, compared to Saint Cyril. Eutychius affirms that Christ had only one nature (monophysitism), the divine one, because - at the embodiment - the human nature was absorbed by the divine one and disappeared completely. The negative consequence of this heresy is that if Christ did not have any relation with the human nature, then the world's salvation is not possible either.

The definition of the $4^{\text {th }}$ Ecumenical Synod, fighting against monophisitism (Eutychius' teaching), shows that in Christ Who is God there are two natures: divine and human, in one hypostasis, "to be acknowledged in two natures, incomfusedly,

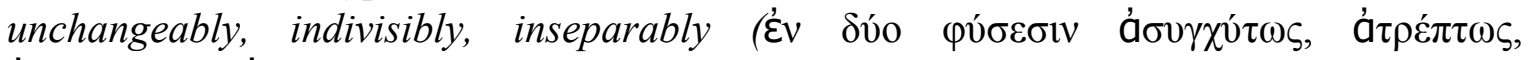

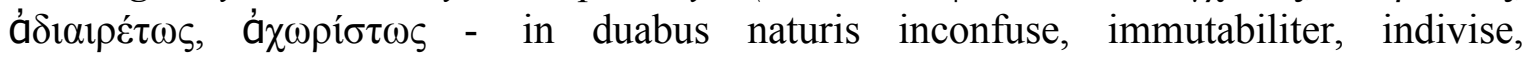
inseparabiliter), the distinction of natures being by no means taken away by the union, but rather the property of each nature being preserved, and concurring in one Person (prosopon) and one hypostasis, not parted or divided into two persons, but one and the same Son, and only begotten God, the Word, the Lord Jesus Christ, as the prophets from the beginning have preached concerning Him and as Jesus Christ Himself has taught us and the Creed of the Holy Fathers has handed down to us", and the Sixth Ecumenical Synod of Constantinople (680-681), fighting against monothelism (heresy claiming that Christ had only the divine will) shows that each nature of God has its own will and work, "the human will submitting itself to His divine and almighty will'[11].

Father Professor Dumitru Stăniloae shows that the expression "in two natures is equivalent to the expression agreed by the pre-Chalcedonian churches of two natures. Because the whole expression sounds as follows: - One and the Same Christ, Son, Lord, One-Born, known in two natures in an unmixed, unchanged, undivided, unseparated way"[12]. The term to be acknowledged refers to the subject, accentuating the unity and the uniqueness of the person or the person of Christ.

The unity of the divine and human nature comprised by the person of Christ is the key to understanding the Christological formula, because: "unity itself is not a compositum, a juxtaposition of parties related in a more or less marked manner between themselves. It is a juxtaposition greater than any juxtaposition" [13]. To clarify the unity of the natures in Christ, important is the theology of Leontius of Byzantium, who by the enhypostatization formula shows that in Christ the human nature is not a stand-alone entity, yet by this observation it does not remain a simple nature without hypostasis, because this thing does not exist, but is included in Him together with the divine nature: "Hypostasis and enhypostasis are not identical as the essence is one and what the essence means is a different thing. The hypostasis points to someone, while enhypostasis points to the essence; the hypostasis delimits the person by its characteristic features; the enhypostasis points out that there is no accident having its existence in another and not considered in itself' [14].

As far as the expression: "one person in two natures" is concerned, it shows that the union with the human nature was real, without the human nature undergoing change; at the same time, the divine nature undergoes no change or blending, each having its own properties, yet collaborating. This teaching reveals Christ the Embodied Son as truly God 
and truly man. Therefore, "the God of the Revelation, the Christian God is love, more precisely agapé - $\alpha \gamma \alpha \pi \eta \ldots$ meaning descending love" [15]. In Christ's Person, God is united to man and the communion is maximal and unique, because they become a perfect unity, without being mixed.

The heart of the Christological formula is the Logos, Who is perfectly God and perfectly man, identical with Jesus Christ. Saint Cyril of Alexandria insists on correctly understanding the fact that the Logos is one. Christ, the Hypostatic Word of the Father: "In the beginning was the Word, and the Word was with God and the Word was God" (John 1:1), eternally born of the being of the Father, is truly God and truly man, having His own Hypostasis in two natures: divine and human, with two wills, possessing all the attributes and features making Him equal to God and to the Holy Spirit: "because there was no time when God the Word was not - as Saint John of Damascus says - God has the power of His Word through Him; is not non-hypostatic... is hypostatic, ...His birth is the act by which is taken out of the being of He Who gives birth the One Who is being born, the same with Him according to the being" [16]. Or as Saint Cyril of Alexandria expresses it, the eternal birth of Christ is: "ontological birth free from any separation, maintaining Him fully connected and coexisting [with the Father]" [17]. In order to avoid the mistaken understanding of the Son as produced from something external to God's being, it is stated: "He is the First Born for us since He has made Himself like us, and One Born, given that it is only He Who came out of God the Father's being" [18].

The Orthodox Chalcedonian Christology includes, in short, the teachings:

1. The identity of the Logos preceding the embodiment with the Logos after the embodiment, namely with Christ.

2. Jesus Christ is true God and true man, consubstantial with the Father according to the divinity, and consubstantial with man according to the humanity assumed completely, except for sin.

3. Jesus Christ is the only begotten before the ages of the Father as God, and the first born in time according to the humanity of Mary the Virgin, as Man.

4. Christ's birth of Mary the Virgin took place for our salvation.

5. Mary the Virgin is Mother of God - Theotokos.

6. Christ's person consists in two natures: divine and human, united without mixture, change, division, separation

7. The union of natures (divine and human), in Christ's person does not suppress the differences between them, each of them keeping their specific properties, with the mention that the human nature, with its will, completely follows the divine will.

The dogmatic definition of the $4^{\text {th }}$ Ecumenical Synod, presents Christ's person as follows: "We, then, following the Holy Fathers, all with one consent, teach men to confess one and the same Son, our Lord Jesus Christ, the same perfect in Godhead and also perfect in manhood; truly God and truly man, of a reasonable soul and body; consubstantial with the Father according to the Godhead, and consubstantial with us according to the Manhood; in all things like us, except for sin; begotten before the ages of the Father according to the Godhead, and in these latter days, for us and for our salvation, born of Mary the Virgin, the Mother of God, according to the Manhead; one and the same Christ, Son, Lord, only begotten, to be acknowledged in two natures unconfusedly, unchangeably, indivisibly, inseparably; the distinction of natures being by no means taken away by the union, but rather the property of each nature being preserved 
and being united in one person and one hypostasis, not parted or divided into two persons, but one and the same Son, and only begotten, God the Word, the Lord Jesus Christ; as the prophets from the beginning have declared concerning Him, and the Lord Jesus Christ Himself has taught us, and the Creed of the Holy Fathers has handed down to us." [19].

Summing up this definition, we shall affirm: Jesus Christ, the Embodied Logos, has a single Person or hypostasis, with two natures: divine and human, with two wills and corresponding actions. The Person of the Embodied Logos remains the sole undivided subject of the two natures. The way of union of the two natures is without division, separation, compoundness or change.

The $4^{\text {th }}$ Ecumenical Synod completes the above-mentioned definition proclaiming, against the monothelites, the following: "We learn to confess in one and the same Christ two natures and two natural activities, in an unseparated and undivided, unchanging and uncompounded manner; at the same time, two natural, not contrary wills, but the human will following and not being opposed or fighting but rather submitting itself to His divine and almighty will.".

The way the union of natures occurred in Christ's person is mysterious. We shall mention that the divine and the human nature have been united in the Word's person by "mutual inhabitation", by interpenetration, called by Saint John of Damascus perichoresis, which expresses at the same time both the two natures and the unity of the person.

\section{CONCLUSIONS}

Our Saviour Jesus Christ is God's Son, the second person of the Holy Trinity Who encompasses the human nature by His birth from the Holy Virgin Mary. By assuming the human nature in Christ's person, it is not the entire Holy Trinity that was embodied, but only the Word, God's Son, and nothing changed in His divine nature, because we know that all the persons of the Holy Trinity are in absolute communion and community.

The formulations and dogmatic definitions of Jesus Christ's Person show that the Son of God took on a human body, made Himself a man assuming in Himself the whole manhood, except for sin, yet He remained truly God. In Christ's person is comprised both the divine nature but also the human nature, united for eternity, in an "uncompounded and unchanging, undivided and inseparable" manner, each nature having its own will, with the mention that the human will completely follows the divine one. This union is eternal and occurred for the benefit of man's and the world's salvation, because the mankind subjected by sin could not have overcome death using its own forces, but in Christ's universal person, by the power of the divine nature, death is defeated for all the people, and this is actually what the resurrection means, as the chant of the Easter celebration proclaims: "Christ is risen from the dead trampling over death by death...".

\section{REFERENCES}

[1] Isidor Todoran, Ioan Zăgrean, Manual de dogmatică ortodoxă pentru seminariile teologice (Textbook of Orthodox Dogmatics for Theological Seminaries), second edition, Editura Renaşterea, Cluj Napoca, 2000, p. 73

[2] Fr. Tache Sterea, Dumnezeu, Omul şi Creaţia în teologia ortodoxă şi în preocupările ecumenismului contemporan (God, Man and the Creation in the Orthodox Theology and in the Contemporary Ecumenistic Concerns), in “Ortodoxia”, XLIX (1998), no. 1-2., p. 68 
[3] Paul Evdokimov, Femeia şi mântuirea lumii (The Woman and the World's Redemption), translated by Gabriela Moldoveanu, Editura Christiana, Bucureşti, 1995, p. 49

[4] Sfântul Ioan Domaschin, Dogmatica (St. John Damascene Dogmatics), Chap.II, translated by Fr. D. Fecioru, Editura Institutului Biblic şi de Misiune al Bisericii Ortodoxe Române (I.B.M.B.O.R.)., Bucureşti, 2001, pp.124-125

[5] Sfântul Vasile cel Mare, Corespondenţe (St. Basil the Great Correspondences), Homily XXXVIII, 2 -3, translated by Fr. Prof. T. Bodogae, in P.S.B. 12, I.B.M.B.O.R., Bucureşti, 1998, p. 178

[6] Sfântul Maxim Mărturisitorul, Scrieri II, Scrieri şi epistole hristologice şi duhovniceşti (St. Maximus the Confessor Writings II. Christological and Spiritual Writings and Epistles), P.S.B., 81, I.B.M.B.O.R., Bucureşti, 1990, p. 131

[7] Sfântul Ioan Gură de Aur, Cateheza II (St. John Chrysostom Catecheses II), PG.49. col 232 apud Rodica Pop. Despre chip și asemanare în scrierile Parintilor Capadocieni (On Image and Likeness in the Cappadocian Fathers' Writings), in vol. Părinţii Capadocieni (Cappadocian Fathers), Editura Fundaţiei Academice, year XIX, Bucureşti 2009, p.404

[8] Paul Evdokimov, op.cit., p. 50

[9] Fr. Prof. Acad. Dr. Dumitru Stăniloae, Studii de teologie dogmatică (Studies of Dogmatic Theology), Editura Mitropoliei Olteniei, 1991, p. 69

[10] Idem, Hristologia Sinoadelor (The Synods' Christology), in S.T, year XXXVI, no. 4 (1974), p. 573.

[11]Fr. Prof. N. Chiţescu, Teologia dogmatică şi simbolică (Dogmatic and Symbolical Theology), vol. II I.B.M., Bucureşti 1956, pp. 584-585

[12]Fr. Prof. D. Stăniloae, Hristologia Sinoadelor (The Synods' Chrystology), in S.T. year XXXVI, no. 4 (1974) p. 575

[13] Ibid, p. 575

[14] Leonţiu de Bizanţ, Contra lui Nestorie (Leontius of Byzantium Contra Nestorianos / Against the Nestorians), P. G. Col 1277,D. 1280 A, apud. Fr. Prof. I. G. Coman, Momente şi aspecte ale hristologiei precalcedoniene şi calcedoniene (Moments and Aspects of the pre-Chalcedonian and Chalcedonian Christology), in Ortodoxia, XVII, (1965), no.1, p. 57

[15]Fr. Constantin Galeriu, Jertfă şi Răscumpărare (Sacrifice and Redemption), Editura Harisma, Bucureşti, 1991, p. 141

[16] Sfântul Ioan Damaschin, Dogmatica (St. John Damascene Dogmatics), VI, VIII, translated by Fr. D. Fecioru, I.B.M, Bucureşti 2001, p. 23, 27-28

[17] Sfântul Chiril al Alexandriei, Comentariul la Evanghelia Sfântului Ioan (St. Cyril of Alexandria Commentary on St. John's Evangel), P.S.B., 41, I.B.M.B.O.R., Bucureşti, p.85

[18] Ibid, IV, p. 159

[19] Prof. N. Chiţescu, Teologia dogmatică..., ed. cit., p.574 